\title{
Efficacy of Epidural Injections in the Treatment of Lumbar Central Spinal Stenosis: A Systematic Review
}

\author{
Laxmaiah Manchikanti ${ }^{1,2,}$; Alan David Kaye ${ }^{3}$; Kavita Manchikanti ${ }^{4}$; Mark Boswell ${ }^{1}$; \\ Vidyasagar Pampati ${ }^{1}$; Joshua Hirsch ${ }^{5}$ \\ ${ }^{1}$ Department of Anesthesiology and Perioperative Medicine, University of Louisville, Louisville, USA \\ 2 Pain Management Center of Paducah, Paducah, USA \\ ${ }^{3}$ Department of Anesthesia, LSU Health Science Center, New Orleans, USA \\ 4 University of Kentucky Medical School, University of Kentucky, Lexington, USA \\ ${ }^{5}$ Massachusetts General Hospital, Harvard Medical School, Boston, MA, USA \\ *Corresponding author: Laxmaiah Manchikanti, Pain Management Center of Paducah, Paducah, USA. Tel:+1-2705548373, Fax: +1-2705548987, E-mail: drlm@thepainmd.com
}

Received: August 29, 2014; Accepted: September 12, 2014

\begin{abstract}
Context: Lumbar central spinal stenosis is common and often results in chronic persistent pain and disability, which can lead to multiple interventions. After the failure of conservative treatment, either surgical or nonsurgical modalities such as epidural injections are contemplated in the management of lumbar spinal stenosis.

Evidence Acquisition: Recent randomized trials, systematic reviews and guidelines have reached varying conclusions about the efficacy of epidural injections in the management of central lumbar spinal stenosis. The aim of this systematic review was to determine the efficacy of all three anatomical epidural injection approaches (caudal, interlaminar, and transforaminal) in the treatment of lumbar central spinal stenosis. A systematic review was performed on randomized trials published from 1966 to July 2014 of all types of epidural injections used in the management of lumbar central spinal stenosis. Methodological quality assessment and grading of the evidence was performed. Results: The evidence in managing lumbar spinal stenosis is Level II for long-term improvement for caudal and lumbar interlaminar epidural injections. For transforaminal epidural injections, the evidence is Level III for short-term improvement only. The interlaminar approach appears to be superior to the caudal approach and the caudal approach appears to be superior to the transforaminal one.

Conclusions:The available evidence suggests thatepidural injections with local anesthetic aloneor with localanesthetic with steroids offer short- and long-term relief of low back and lower extremity pain for patients with lumbar central spinal stenosis. However, the evidence is Level II for the long-term efficacy of caudal and interlaminar epidural injections, whereas it is Level III for short-term improvement only with transforaminal epidural injections.
\end{abstract}

Keywords:Injections; local Anesthetic; Pain

\section{Context}

Lumbar central spinal stenosis is defined as narrowing of the spinal canal, secondary to disc herniation, protrusion, extrusion and disc bulging combined with osteophytes and arthritic changes of the facet joints, resulting in symptoms and signs caused by entrapment and compression of the intraspinal, vascular and nervous structures $(1,2)$. Central spinal stenosis, prevalent in $27.2 \%$ of the population $(1,2)$, is a multifactorial disorder with a variable clinical presentation with or without neurogenic claudication manifested by pain in a buttock or leg when walking, which disappears with sitting or lumbar flexion (3). Thus, symptoms of central spinal stenosis may be related to a neurovascular mechanism such as arterial flow in cauda equina, venous congestion, and increased epidural pressure, nerve root excitation by local inflammation, or direct compression in the central canal (1-4). While surgery is the most common intervention performed for lumbar spinal stenosis (5-9), epidural injections are common nonsurgical interventions (10-15). The goal of sur- gery is to decompress the thecal sac from the spinal canal compromise; whereas, the goal of epidural injections is to suppress pain response and improve function by various mechanisms, including an anti-inflammatory effect (10, 16). The effectiveness of epidural injections in the management of lumbar central spinal stenosis has been under debate. Many authors compared the effectiveness of surgical interventions with epidural injections. They reported lack of efficacy of epidural injections in the management of chronic pain and disability of central spinal stenosis (17-19). Similar results were echoed by others (20-23). However, multiple systematic reviews (24-26) and randomized trials demonstrated clinical efficacy and cost effectiveness of epidural injections in managing pain of central spinal stenosis (20, 27-33). Furthermore, despite the gold standard status of surgical intervention, the efficacy and safety of surgical interventions have been questioned (5-9, 34-41). Even so, using surgery for spinal stenosis has been escalating, resulting in multiple complications and

Copyright (C) 2015, Iranian Society of Regional Anesthesia and Pain Medicine(ISRAPM). This is an open-access article distributed under the terms of the Creative Commons Attribution-NonCommercial 4.0 International License (http://creativecommons.org/licenses/by-nc/4.0/) which permits copy and redistribute the material just in noncommercial usages, provided the original work is properly cited. 
even fatalities (5-9, 38-41). Consequently, multiple minimally invasive surgical interventions have been studied for their use (42-46). The quality-adjusted life year (QALY) for open surgery has been estimated as $\$ 77600$ (CI $\$ 49600$ to $\$ 120000$ ) (47). A cost-effectiveness analysis showed a favorable cost utility for caudal epidural injections in contemporary interventional pain management settings (31). However, in some reviews $(17,22,23)$, using inappropriate criteria and data, cost utility analysis was not demonstrated for epidural injections $(31,48)$. A recent study by Friedly et al. (20), performed in multiple settings by 26 pain physicians on 400 patients, included a design which is not amenable to assess outcomes in central spinal stenosis with an interventional technique, namely epidural injections. Similar to the systematic review performed by the same authors (23) which excluded the randomized trials, Friedly et al. (20) excluded available high-quality randomized trials, yet they included low-quality trials. Furthermore, their follow-up was only six weeks, using either interlaminar or transforaminal techniques with variable volumes of injections. They reported an inordinate amount of adverse events, poorly interpreted the outcome results and reached inappropriate conclusions (33).

\section{Evidence Acquisition}

The evidence is highly debatable and often biased in reference to epidural injections (10,16-18, 22-26, 29-31, 48, 49). Central spinal stenosis has been treated with percutaneous adhesiolysis, which is also an epidural injection involving catheter passage and injection of multiple drugs $(10,49-56)$; however, this was not included in the present analysis.

The aim of this systematic review was to determine the efficacy of all three anatomical epidural injection approaches (caudal, interlaminar and transforaminal) in the treatment of lumbar spinal stenosis.

The methodology used in this systematic review followed the established and widely accepted process derived from multiple evidence-based systematic reviews and meta-analyses of randomized trials (57-59). Only randomized controlled trials were used, either placeboor active-controlled. The true definition of placebo is to inject an inactive substance into an inactive structure. For this review, we considered an injection of a placebo into the epidural space or over the nerve root by any approach as a placebo, even though it is an impure placebo (60-62). The studies were eligible if the assessment was performed for central lumbar spinal stenosis with or without neurogenic claudication. For this evaluation, only studies including patients with chronic symptoms of at least three months were considered. Trials including radiculitis secondary to disc herniation, foraminal stenosis, discogenic pain, post-surgery syndrome, or spinal stenosis in post-surgery syndrome and chemical radiculitis were not included in this review. However, trials with multiple groups of patients were included if an appropriate analysis was separately provided for patients with central spinal stenosis. The primary outcome measure was pain relief. The secondary outcome measure was functional status improvement. A literature search was performed covering the period from 1966 to July 2014 using data from PubMed, the Cochrane library, the US National Guideline Clearinghouse (NGC), previous systematic reviews and cross references. The search strategy emphasized low back and lower extremity pain, central spinal stenosis, radiculitis and neurogenic claudication treated with either caudal, interlaminar or transforaminal epidural injections. Search Terms were as follows: ((((epidural steroid injection) OR ESI) OR epidural steroid injections $))$ AND ((((spinal stenosis[MeSH Terms]) OR Spinal Stenosis[Title/Abstract]) OR sciatica[MeSH Terms]) OR sciatica[Title/Abstract]).

The quality of each article used in this analysis was assessed using Cochrane review criteria for randomized trials as shown in Table 1 (57) and Interventional Pain Management Techniques Quality Appraisal of Reliability and Risk of Bias Assessment (IPM-QRB) for methodological quality assessment of randomized trials as shown in Table 2 (63). Cochrane review criteria were used over the years to assess all types of randomized trials. In contrast, IPM-QRB methodological quality assessment criteria for randomized trials include an expanded and detailed analysis of methodological quality and bias assessment specifically developed for interventional techniques. Only randomized trials meeting the inclusion criteria with at least 5 of 12 scores on Cochrane review criteria and/or 20 of 48 on the IPM-QRB were included. A meta-analysis was conducted if more than two randomized trials were homogeneous. At least two of the review authors independently, in an unblinded, standardized manner, performed each search and methodological quality assessment. The primary authors of manuscripts were not involved in the methodological quality assessment. All searches were combined to obtain a unified strategy. Any disagreements between reviewers were resolved by a third author (JAH) and consensus. The evidence analysis was conducted based on the qualitative level of evidence, using the modified approach to evidence grading shown in Table 3 (64). This was developed from multiple previously used grading schemata, most importantly Cochrane reviews and the United States Preventative Services Task Force (USPSTF) (10, 59, 65, 66). Summary measures included a $50 \%$ or more reduction in pain in at least $50 \%$ of patients or at least a 3-point decrease in pain scores and a relative risk for adverse events, including side effects. Randomized trials were judged to be positive if the injection therapy was clinically relevant and effective, either with a placebo control or active control, with a difference in effect for the primary outcome measure to be statistically significant at the conventional 5\% level. Any improvement of less than six months was considered as short-term; six months or longer was considered as longterm. Furthermore, the outcomes were judged at the reference point with efficacy present or absent with results reported at three months, six months and one year. 
Table 1. Cochrane Randomized Controlled Trials Quality Rating System a

Controlled Trials Quality

A 1. Was the method of ran- A random (unpredictable) assignment sequence. Examples of adequate methods are coin toss (for stud- Yes/No/Unsure domization adequate? ies with two groups), rolling a dice (for studies with two or more groups), drawing of balls of differen colors, drawing of ballots with the study group labels from a dark bag, computer-generated random sequence, pre-ordered sealed envelopes, sequentially-ordered vials, telephone call to a central office, and pre-ordered list of treatment assignments. Examples of inadequate methods are alternation, birth date, social insurance/security number, date in which they are invited to participate in the study and hospital registration number.

B 2. Was the treatment allocation concealed?

Assignment generated by an independent person not responsible for determining the eligibility of patients. This person has no information about persons included in the trial and has no influence on the assignment sequence or on the decision about eligibility of patient.

C Was knowledge of the

allocated interventions

adequately prevented during the study?

3. Was the patient blinded to This item should be scored "yes" if the index and control groups are indistinguishable for patients or if Yes/No/Unsure the intervention?

4. Was the care provider blinded to the intervention?

5. Was the outcome assessor blinded to the intervention? ers or if the success of blinding was tested among care providers and it was successful.

Adequacy of blinding should be assessed for the primary outcomes. This item should be scored "yes" if the Yes/No/Unsure success of blinding was tested among the outcome assessors and it was successful or:-for patient-reported outcomes in which the patient is the outcome assessor (e.g., pain, disability): the blinding procedure is adequate for outcome assessors if participant blinding is scored "yes";-for outcome criteria assessed during scheduled visit and that supposes a contact between participants and outcome assessors (e.g., clinical examination): the blinding procedure is adequate if patients are blinded, and the treatment or adverse effects of the treatment cannot be noticed during clinical examination;-for outcome criteria that do not suppose a contact with participants (e.g., radiography, magnetic resonance imaging): the blinding procedure is adequate if the treatment or adverse effects of the treatment cannot be noticed when assessing the main outcome; -for outcome criteria that are clinical or therapeutic events that would be determined by the interaction between patients and care providers (e.g., co-interventions, hospitalization length, treatment failure), in which the care provider is the outcome assessor: the blinding procedure is adequate for outcome assessors if item "4" (caregivers) is scored "yes"; -for outcome criteria that are assessed from data of medical forms: the blinding procedure is adequate if the treatment or adverse effects of the treatment cannot be noticed on the extracted data.

D Were incomplete outcome data adequately addressed?

6. Was the drop-out rate described and acceptable?

The number of participants who were included in the study, but did not complete the observation period Yes/No/Unsure or were not included in the analysis must be described and reasons given. If the percentage of withdrawals and drop-outs does not exceed $20 \%$ for short-term follow-up and 30\% for long-term follow-up and does not lead to substantial bias a "yes" is scored.

7. Were all randomized participants analyzed in th group to which they were allocated?

E 8.Are reports of the study free of suggestion of selec tive outcome reporting?

All randomized patients are reported/analyzed in the group they were allocated to by randomization for Yes/No/Unsure the most important moments of effect measurement (minus missing values) irrespective of non-compliance and co-interventions.

To receive a "yes," the review author determines if all the results from all pre-specified outcomes have been Yes/No/Unsure adequately reported in the published report of the trial. This information is either obtained by comparing the protocol and the report, or in the absence of the protocol, assessing that the published report includes enough information to make this judgment.

F Other sources of potential bias

9. Were the groups similar at baseline regarding the most important prognostic indicators?

10. Were co-interventions avoided or similar?

11. Was the compliance acceptable in all groups?

12. Was the timing of outcome assessment similar in

To receive a "yes," groups have to be similar at baseline regarding demographic factors, duration and severity of complaints, percentage of patients with neurological symptoms and value of main outcome measure(s).

This item should be scored "yes" if there were no co-interventions or they were similar between the index Yes/No/Unsure and control groups.

The reviewer determines if the compliance with the interventions is acceptable, based on the reported Yes/No/Unsure intensity, duration, number and frequency of sessions for both the index intervention and control

intervention(s). For example, physiotherapy treatment is usually administered over several sessions;

therefore, it is necessary to assess how many sessions each patient attended. For single-session interventions (e.g., surgery), this item is irrelevant.

Timing of outcome assessment should be identical for all intervention groups and for all important Yes/No/Unsure outcome assessments.

$$
\text { all groups? }
$$

a Adapted and Modified: Furlan AD, Pennick V, Bombardier C, van Tulder Ml; Editorial Board, Cochrane Back Review Group. 2009 updated method guidelines for systematic reviews in the Cochrane Back Review Group. Spine (Phila Pa 1976) 2009; 34:1929-1941 (57). 
Table 2. Item Checklist for Assessment of Randomized Controlled Trials of IPM Techniques Using Interventional Pain Management Techniques-Quality Appraisal of Reliability and Risk of Bias Assessment (IPM-QRB) ${ }^{\mathrm{a}}$

\begin{tabular}{|c|c|c|}
\hline & & Scoring \\
\hline I & Trial design guidance and reporting & \\
\hline \multirow[t]{5}{*}{1} & Consort or Spirit & \\
\hline & Trial designed and reported without any guidance & 0 \\
\hline & Trial designed and reported using minimum criteria other than CONSORT or SPIRIT criteria or trial was conducted prior to 2005 & 1 \\
\hline & $\begin{array}{c}\text { Trial implies it was based on CONSORT or SPIRIT without clear description with moderately significant criteria for randomized } \\
\text { trials or the trial was conducted before } 2005\end{array}$ & 2 \\
\hline & $\begin{array}{c}\text { Explicit use of CONSORT or SPIRIT with identification of criteria or trial conducted with high level reporting and criteria or con- } \\
\text { ducted before } 2005\end{array}$ & 3 \\
\hline II & DESIGN FACTORS & \\
\hline \multirow[t]{4}{*}{2} & Type and design of trial & \\
\hline & Poorly designed control group (quasi selection, convenient sampling) & 0 \\
\hline & Proper active-control or sham procedure with injection of active agent & 2 \\
\hline & Proper placebo control (no active solutions into active structures) & 3 \\
\hline \multirow[t]{4}{*}{3} & Setting/Physician & \\
\hline & General setting with no specialty affiliation and general physician & 0 \\
\hline & Specialty of anesthesia/PMR/neurology/radiology/ortho, etc. & 1 \\
\hline & Interventional pain management with interventional pain management physician & 2 \\
\hline \multirow[t]{5}{*}{4} & Imaging & \\
\hline & Blind procedures & 0 \\
\hline & Ultrasound & 1 \\
\hline & $\mathrm{CT}$ & 2 \\
\hline & Fluoro & 3 \\
\hline \multirow[t]{5}{*}{5} & Sample size & \\
\hline & Less than 50 participants in the study without appropriate sample size determination & 0 \\
\hline & Sample size calculation with less than 25 patients in each group & 1 \\
\hline & Appropriate sample size calculation with at least 25 patients in each group & 2 \\
\hline & Appropriate sample size calculation with 50 patients in each group & 3 \\
\hline \multirow[t]{3}{*}{6} & Statistical methodology & \\
\hline & None or inappropriate & 0 \\
\hline & Appropriate & 1 \\
\hline III & PATIENT FACTORS & \\
\hline 7 & Inclusiveness of population & \\
\hline \multirow[t]{4}{*}{$7 a$} & For epidural procedures: & \\
\hline & Poorly identified mixed population & 0 \\
\hline & Clearly identified mixed population & 1 \\
\hline & $\begin{array}{l}\text { Disorders specific trials (i.e. well defined spinal stenosis and disc herniation, disorder specific, disc herniation or spinal stenosis or } \\
\text { post surgery syndrome) }\end{array}$ & 2 \\
\hline \multirow[t]{4}{*}{$7 \mathrm{~b}$} & For facet or sacroiliac joint interventions: & \\
\hline & No diagnostic blocks & 0 \\
\hline & Selection with single diagnostic blocks & 1 \\
\hline & Selection with placebo or dual diagnostic blocks & 2 \\
\hline \multirow[t]{4}{*}{8} & Duration of pain & \\
\hline & Less than 3 months & 0 \\
\hline & 3 to 6 months & 1 \\
\hline & $>6$ months & 2 \\
\hline \multirow[t]{5}{*}{9} & Previous treatments & \\
\hline & Conservative management including drug therapy, exercise therapy, physical therapy, etc. & \\
\hline & Were not used & 0 \\
\hline & Were used sporadically in some patients & 1 \\
\hline & Were used in all patients & 2 \\
\hline \multirow[t]{5}{*}{10} & Duration of follow-up with appropriate interventions & \\
\hline & $\begin{array}{c}\text { Less than } 3 \text { months or } 12 \text { weeks for epidural or facet joint procedures, etc. and } 6 \text { months for intradiscal procedures and im- } \\
\text { plantables }\end{array}$ & 0 \\
\hline & 3 to 6 months for epidural or facet joint procedures, etc., or 1 year for intradiscal procedures or implantables & 1 \\
\hline & 6 months to 17 months for epidurals or facet joint procedures, etc., and 2 years or longer for discal procedures and implantables & 2 \\
\hline & 18 months or longer for epidurals and facet joint procedures, etc., or 5 years or longer for discal procedures and implantables & 3 \\
\hline IV & Outcomes & \\
\hline 11 & Outcomes assessment criteria for significant improvement & \\
\hline
\end{tabular}


No descriptions of outcomes $\mathrm{OR}<20 \%$ change in pain rating or functional status

Pain rating with a decrease of 2 or more points or more than $20 \%$ reduction or functional status improvement of more than $20 \%$

Pain rating with decrease of $\geq 2$ points and $\geq 20 \%$ change or functional status improvement of $\geq 20 \%$

0

\begin{tabular}{|c|c|c|}
\hline & Pain rating with a decrease of 2 or more points or more than $20 \%$ reduction or functional status improvement of more than $20 \%$ & 1 \\
\hline & Pain rating with decrease of $\geq 2$ points and $\geq 20 \%$ change or functional status improvement of $\geq 20 \%$ & 2 \\
\hline & $\begin{array}{c}\text { Pain rating with a decrease of } 3 \text { or more points or more than } 50 \% \text { reduction or functional status improvement with a } 50 \% \text { or } 40 \% \\
\text { reduction in disability score }\end{array}$ & 2 \\
\hline & Significant improvement with pain and function $\geq 50 \%$ or 3 points and $40 \%$ reduction in disability scores & 4 \\
\hline \multirow[t]{4}{*}{12} & Analysis of all randomized participants in the groups & \\
\hline & Not performed & 0 \\
\hline & Performed without intent-to-treat analysis without inclusion of all randomized participants & 1 \\
\hline & All participants included with or without intent-to-treat analysis & 2 \\
\hline \multirow[t]{4}{*}{13} & Description of drop-out rate & \\
\hline & No description of dropouts, despite reporting of incomplete data or less than $20 \%$ withdrawal & 0 \\
\hline & Less than $20 \%$ withdrawal in one year in any group & 1 \\
\hline & Less than $30 \%$ withdrawal at 2 years in any group & 2 \\
\hline \multirow[t]{4}{*}{14} & Similarity of groups at baseline for important prognostic indicators & \\
\hline & Groups dissimilar with significant influence on outcomes with or without appropriate randomization and allocation & 0 \\
\hline & Groups dissimilar without influence on outcomes despite appropriate randomization and allocation & 1 \\
\hline & Groups similar with appropriate randomization and allocation & 2 \\
\hline \multirow[t]{3}{*}{15} & Role of co-interventions & \\
\hline & Co-interventions were provided but were not similar participants & 0 \\
\hline & No co-interventions or similar co-interventions were provided in most participants & 1 \\
\hline $\mathbf{V}$ & RANDOMIZATION & \\
\hline 16 & Method of randomization & \\
\hline
\end{tabular}

Quasi randomized or poorly randomized or not described

High quality randomization (Computer generated random sequence, pre-ordered sealed envelopes, sequentially ordered vials, 2 telephone call, pre-ordered list of treatment assignments, etc.)

$\begin{array}{lc}\text { VI } & \text { Allocation Concealment } \\ 17 & \text { Concealed treatment allocation }\end{array}$

Poor concealment of allocation (open enrollment) or inadequate description of concealment Concealment of allocation with borderline or good description of the process with probability of failure of concealment High quality concealment with strict controls (independent assignment without influence on the assignment sequence)

VII

18

19

20

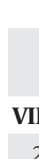

VIII

21 Outcome assessor not blinded or was able to identify the groups Blinding Patient blinding Patients not blinded Patients blinded adequately Care provider blinding Care provider not blinded Care provider blinded adequately Performed by a blinded independent assessor with inability to identify the assignment-based provider intervention (i.e., subcutaneous injection, intramuscular distant injection, difference in preparation or equipment use, numbness and weakness, etc.)

Conflicts of interest

Funding and sponsorship Trial included industry employees

Industry employees involved; high levels of funding with remunerations by industry or an organization funded with conflicts Industry or organizational funding with reimbursement of expenses with some involvement Industry or organization funding of expenses without involvement

Funding by internal resources only with supporting entity unrelated to industry Governmental funding without conflict such as NIH, NHS, AHRQ Conflicts of interest Well disclosed with minor conflicts Well disclosed with no conflicts Hidden conflicts with poor disclosure Misleading disclosure with conflicts

(1)

\begin{tabular}{|lcl}
\hline & None disclosed with potential implied conflict & 0 \\
& Marginally disclosed with potential conflict & 2 \\
\hline & Well disclosed with minor conflicts \\
\hline & Well disclosed with no conflicts \\
\hline Total & Hidden conflicts with poor disclosure \\
\hline & Misleading disclosure with conflicts \\
\hline & Major impact related to conflicts \\
\hline
\end{tabular}

Total

a Source: Manchikanti L, et al. Assessment of methodological quality of randomized trials of interventional techniques: Development of an interventional pain management specific instrument. Pain Physician 2014; 17:E263-E290 (63). 
Manchikanti L et al.

\begin{tabular}{|c|c|}
\hline & Results \\
\hline Level I & Evidence obtained from multiple relevant high quality randomized controlled trials \\
\hline Level II & $\begin{array}{l}\text { Evidence obtained from at least one relevant high quality randomized controlled trial or multiple relevant moderate or } \\
\text { low quality randomized controlled trials }\end{array}$ \\
\hline Level III & $\begin{array}{l}\text { Evidence obtained from at least one relevant moderate or low quality randomized controlled trial with multiple } \\
\text { relevant observational studies or evidence obtained from at least one relevant high quality nonrandomized trial or } \\
\text { observational study with multiple moderate or low quality observational studies }\end{array}$ \\
\hline Level IV & Evidence obtained from multiple moderate or low quality relevant observational studies \\
\hline Level V & Opinion or consensus of large group of clinicians and/or scientists \\
\hline
\end{tabular}

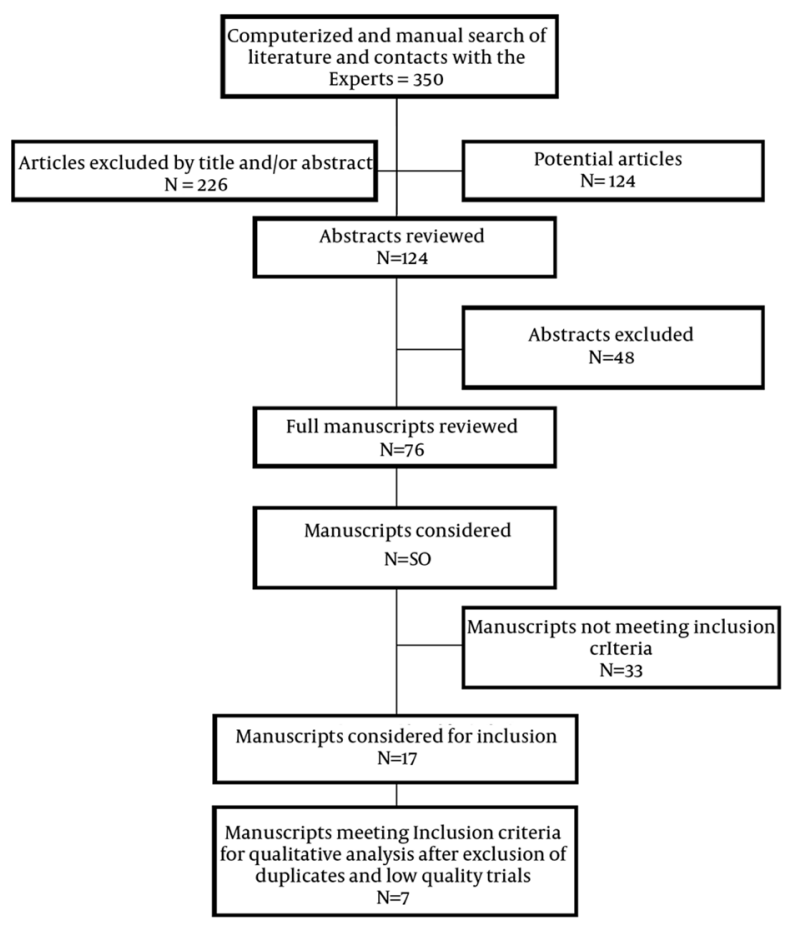

Figure 1. A flow Diagram Illustrating Published Literature Evaluating Epidural Injections in Lumbar Central Spinal Stenosis

\section{Results}

Figure 1 shows a flow diagram of the study selection as recommended by Preferred Reporting Items for Systematic Reviews and Meta-Analyses (PRISMA) (58). Overall, 17 randomized trials were considered for inclusion, of which 7 met the inclusion criteria $(29,30,67-71)$. Two trials were excluded due to their failure to meet the inclusion criteria; one was a low quality trial (72) and the other had a limited 6-week follow-up (20). This trial, by Friedly et al. (20), was a large trial of 400 patients assessing the role of interlaminar and transforaminal epidural injections, but it had a follow-up of only six weeks. For interventional procedures, six weeks of follow-up is extremely limited.
In addition, they also included a significant number of patients with acute pain. Thus, this trial did not meet the inclusion criteria.

\subsection{Methodological Quality Assessment}

The methodological quality assessment of randomized controlled trials is presented in Tables 4 and 5 for fluoroscopically and non-fluoroscopically guided randomized trials. Among seven trials assessed for methodological quality, there were two high-quality trials based on both Cochrane review criteria and IPB-QRB criteria (29, 30); two trials $(67,71)$ were high-quality based on Cochrane review criteria and moderate-quality based on IPM-QRB criteria. There were two trials of moderate-quality (68, 69) based on both Cochrane review criteria and IPM-QRB criteria. There was also one moderate quality trial (70) based on Cochrane review criteria and low quality based on IPM-QRB criteria (72). One trial was excluded due to low quality by both assessment criteria (72).

4.2. Study Characteristics

Study characteristics of the included trials are shown in Table 6. Of seven randomized controlled trials meeting the inclusion criteria, there was one caudal trial (29) of high-quality based on both Cochrane review criteria as well as IPM-QRB criteria; four interlaminar epidural trials $(30,68-71)$, of which there was only one high-quality randomized controlled trial (30) based on both Cochrane review criteria and IPM-QRB criteria, one trial (71) which was of high-quality based on Cochrane review criteria and moderate-quality based on IPM-QRB criteria, two trials were of moderate-quality $(68,69)$ based on Cochrane review as well as IPM-QRB, one trial (70) was of moderate-quality based on Cochrane review criteria and low-quality based on IPM-QRB criteria, and one (72) was of low-quality using both Cochrane review as well as IPM-QRB criteria. There were two trials (67, 68 ) assessing the role of transforaminal epidural injections in central spinal stenosis with one (67) being highquality with Cochrane review criteria, whereas it was of moderate-quality on IPM-QRB criteria. The second trial (68) of transforaminal was of moderate-quality on both Cochrane review criteria as well as IPM-QRB criteria. 
Manchikanti L et al.

\begin{tabular}{|c|c|c|c|c|c|c|c|c|}
\hline & $\begin{array}{l}\text { Manchikanti } \\
\text { et al. (29) }\end{array}$ & $\begin{array}{l}\text { Manchikanti } \\
\text { et al. (30) }\end{array}$ & $\begin{array}{c}\text { Lee et al. } \\
\quad(68)\end{array}$ & $\begin{array}{l}\text { Koc et } \\
\text { al. }(69)\end{array}$ & $\begin{array}{l}\text { Wilson-MacDonald } \\
\text { et al. ( } 71 \text { ) }\end{array}$ & $\begin{array}{l}\text { Fukusaki et } \\
\text { al.(70) }\end{array}$ & $\begin{array}{l}\text { Nam and } \\
\text { Park }(67)\end{array}$ & $\begin{array}{l}\text { Milburn et } \\
\text { al. (72) }\end{array}$ \\
\hline Randomization adequate & $\mathrm{Y}$ & $\mathrm{Y}$ & $\mathrm{N}$ & $\mathrm{U}$ & $\mathrm{Y}$ & $\mathrm{N}$ & $\mathrm{Y}$ & $\mathrm{N}$ \\
\hline Concealed treatment allocation & Y & Y & $\mathrm{N}$ & $\mathrm{N}$ & $\mathrm{Y}$ & $\mathrm{N}$ & $\mathrm{N}$ & $\mathrm{N}$ \\
\hline Patient blinded & Y & Y & $\mathrm{N}$ & $\mathrm{N}$ & Y & $\mathrm{N}$ & Y & Y \\
\hline Care provider blinded & Y & Y & $\mathrm{N}$ & $\mathrm{N}$ & $\mathrm{N}$ & $\mathrm{N}$ & $\mathrm{N}$ & $\mathrm{N}$ \\
\hline Outcome assessor blinded & $\mathrm{N}$ & $\mathrm{N}$ & $\mathrm{N}$ & $\mathrm{N}$ & Y & $\mathrm{U}$ & $\mathrm{N}$ & $\mathrm{Y}$ \\
\hline Drop-out rate described & Y & Y & Y & Y & Y & $\mathrm{N}$ & Y & $\mathrm{N}$ \\
\hline $\begin{array}{l}\text { All randomized participants } \\
\text { analyzed in the group }\end{array}$ & Y & Y & $\mathrm{N}$ & $\mathrm{N}$ & Y & Y & $\mathrm{N}$ & Y \\
\hline $\begin{array}{l}\text { Reports of the study free of } \\
\text { suggestion of selective outcome } \\
\text { reporting }\end{array}$ & Y & Y & Y & Y & Y & Y & Y & $\mathrm{U}$ \\
\hline $\begin{array}{l}\text { Groups similar at baseline } \\
\text { regarding most important } \\
\text { prognostic indicators }\end{array}$ & Y & $\mathrm{N}$ & Y & Y & $\mathrm{N}$ & Y & Y & $\mathrm{N}$ \\
\hline $\begin{array}{l}\text { Co-interventions avoided or } \\
\text { similar }\end{array}$ & Y & Y & Y & Y & Y & $\mathrm{N}$ & Y & $\mathrm{N}$ \\
\hline $\begin{array}{l}\text { Compliance acceptable in all } \\
\text { groups }\end{array}$ & Y & Y & Y & $\mathrm{N}$ & Y & Y & Y & $\mathrm{N}$ \\
\hline $\begin{array}{l}\text { Time of outcome assessment in } \\
\text { all groups similar }\end{array}$ & Y & Y & Y & Y & Y & Y & Y & $\mathrm{N}$ \\
\hline Score & $11 / 12$ & $10 / 12$ & $6 / 12$ & $5 / 12$ & $10 / 12$ & $5 / 12$ & $8 / 12$ & $3 / 12$ \\
\hline
\end{tabular}

The caudal epidural injection trial by Manchikanti et al. (29) studied 100 patients, with 50 assigned to the lidocaine only group and 50 assigned to the lidocaine with steroid group. They used appropriate outcome measures and provided long-term follow-up results of two years in a double-blind active controlled design; however, there was no placebo control group. In addition, in allocating patients into nonresponsive and responsive groups, they showed that $26 \%$ of patients, 13 in each group, were nonresponsive, an inordinately high proportion. Overall, when considering successful or responsive patients, efficacy was shown in $54 \%$ in the local anesthetic only group and $62 \%$ in the local anesthetic with steroid groups. This proportion decreased to $51 \%$ and $57 \%$, respectively, at the end of two years. Among the interlaminar epidural trials, there was only one highquality trial. It was conducted by Manchikanti et al. (30). This trial assessed 120 patients who underwent an interlaminar approach. Sixty patients were in the local anesthetic only group and 60 were in the local anesthetic with steroid group. Similar to the caudal epidural trial (29), which was based on the same protocol, there was no placebo control, even though this was a large active controlled trial with a 2-year follow-up and appropriate outcome parameters. Interestingly, this trial had a smaller number of patients who were nonresponsive to the initial two procedures; 9 of 60 in the local anesthetic group and 7 of 60 in the steroid group.

Furthermore, in patients who were responsive to the first two injections of local anesthetic only, efficacy was continued in $86 \%$ at the end of one year; for the group who re- ceived local anesthetic with steroid, it was $83 \%$. Similarly, at the end of two years, $84 \%$ in the local anesthetic only group reported continued efficacy; whereas, it was $85 \%$ in the local anesthetic with steroid group. Lee et al. in a moderate-quality trial (68), compared interlaminar epidural injections with bilateral transforaminal epidural injections. Bilateral transforaminal epidural injections are considered high risk and are not generally recommended. Even though the outcomes were appropriately assessed, the sample size was very small, with significant relief assessed only at 3-month follow-up. Even though the results were positive, it was difficult to draw conclusions based on these criteria. Furthermore, they lacked a placebo control as well as a comparison with local anesthetic only group. Koc et al. (69), in a moderate-quality assessment, studied a very small number of patients in two groups, 10 patients in each, who received either inpatient physical therapy or epidural steroid injections; there was a control group of nine patients. They reported significant and similar improvement in all three groups at 6-month follow-up. This was also a very small study with positive results; however, due to the extremely small sample size and moderate-quality design with similar results in all the three groups and an impractical design with inpatient physical therapy, it was difficult to draw conclusions. Wilson-MacDonald (71), in a high-quality tri$\mathrm{al}$, included patients who had disc herniation and spinal stenosis. Thus, the quality was considered as only moderate based on IPM-QRB criteria because of the small number of patients who underwent epidural injections or in the control group with spinal stenosis. The sample size 
was not based on the group of patients with spinal stenosis. The results could only be determined at 35 days and after that we were unable to determine the results. This was a small study and significant difference could only be determined at 35 days, even though, patients were followed for one year. The results were inconclusive despite the inclusion of a placebo group in this trial. Fukusaki et al. (70), in a moderate-quality trial, assessed a small number of patients in three groups with a short-term followup. The study limitations precluded their forming any opinions or reaching a conclusion. There were two transforaminal epidural trials. One was of high-quality based on Cochrane review criteria and moderate-quality based on IPM-QRB criteria (67). This trial had 36 patients, with 19 patients in the lidocaine only group and 17 patients in the lidocaine with steroid group. Apart from being a small trial, only 3-month outcomes were available. In addition, there was no placebo group. Nevertheless, the authors reported superiority for steroids. The second trial, by Lee et al. (68), compared interlaminar injections with bilateral transforaminal epidural injections, a high-risk technique. This small study, without a placebo group or a comparative local anesthetic with steroid group, did not provide significant evidence.

\begin{tabular}{|c|c|c|c|c|c|c|c|c|c|}
\hline & & $\begin{array}{c}\text { Manchikanti et } \\
\text { al.(29) }\end{array}$ & $\begin{array}{c}\text { Manchikanti et } \\
\text { al.(30) }\end{array}$ & $\begin{array}{c}\text { Lee et al. } \\
(68)\end{array}$ & $\begin{array}{l}\text { Koc et } \\
\text { al.(69) }\end{array}$ & $\begin{array}{c}\text { Wilson-MacDonald } \\
\text { et al. (71) }\end{array}$ & $\begin{array}{c}\text { Fukusaki et } \\
\text { al.(70) }\end{array}$ & $\begin{array}{l}\text { Nam and } \\
\text { Park(67) }\end{array}$ & $\begin{array}{c}\text { Milburn et } \\
\text { al.(72) }\end{array}$ \\
\hline I & Consort or Spirit & & & & & & & & \\
\hline 1 & $\begin{array}{l}\text { Trial Design Guidance and } \\
\text { Reporting }\end{array}$ & 3 & 3 & 2 & 2 & 3 & 0 & 0 & 0 \\
\hline II & Design Factors & & & & & & & & \\
\hline 2 & Type and Design of Trial & 2 & 2 & 2 & 0 & 2 & 2 & 2 & 2 \\
\hline 3 & Setting/Physician & 2 & 2 & 1 & 1 & 1 & 1 & 2 & 2 \\
\hline 4 & Imaging & 3 & 3 & 3 & 3 & 0 & 0 & 3 & 0 \\
\hline 5 & Sample Size & 3 & 3 & 1 & 0 & 0 & 0 & 0 & 0 \\
\hline 6 & Statistical Methodology & 1 & 1 & 1 & 1 & 1 & 1 & 1 & 0 \\
\hline III & Patient Factors & & & & & & & & \\
\hline 7 & Inclusiveness of Population & & & & & & & & \\
\hline $7 a$ & For epidural procedures: & 2 & 2 & 1 & 1 & 1 & 2 & 2 & 2 \\
\hline $7 b$ & $\begin{array}{l}\text { For facet or sacroiliac joint } \\
\text { interventions: }\end{array}$ & & & & & & & & \\
\hline 8 & Duration of Pain & 2 & 2 & 1 & 1 & 2 & 1 & 1 & 1 \\
\hline 9 & Previous Treatments & 2 & 2 & 2 & 2 & 2 & 0 & 0 & 0 \\
\hline 10 & $\begin{array}{l}\text { Duration of Follow-up with } \\
\text { Appropriate Interventions }\end{array}$ & 3 & 3 & 1 & 1 & 1 & 1 & 0 & 1 \\
\hline IV & Outcomes & & & & & & & & \\
\hline 11 & $\begin{array}{l}\text { Outcomes Assessment Criteria } \\
\text { for Significant Improvement }\end{array}$ & 4 & 4 & 2 & 2 & 2 & 1 & 2 & 1 \\
\hline 12 & $\begin{array}{l}\text { Analysis of all Randomized } \\
\text { Participants in the Groups }\end{array}$ & 2 & 2 & 2 & 2 & 2 & 1 & 2 & 0 \\
\hline 13 & Description of Drop-out Rate & 2 & 2 & 1 & 1 & 1 & 1 & 1 & 1 \\
\hline 14 & $\begin{array}{l}\text { Similarity of Groups at Base- } \\
\text { line for Important Prognostic } \\
\text { Indicators }\end{array}$ & 1 & 0 & 1 & 1 & 1 & 1 & 2 & 0 \\
\hline 15 & Role of Co-Interventions & 1 & 1 & 1 & 1 & 1 & 0 & 1 & 0 \\
\hline $\mathbf{V}$ & Randomization & & & & & & & & \\
\hline 16 & Method of Randomization & 2 & 2 & 0 & 0 & 2 & 1 & 1 & 0 \\
\hline VI & Allocation Concealment & & & & & & & & \\
\hline 17 & $\begin{array}{c}\text { Concealed Treatment Alloca- } \\
\text { tion }\end{array}$ & 2 & 2 & 0 & 0 & 2 & 0 & 0 & 0 \\
\hline VII & Blinding & & & & & & & & \\
\hline 18 & Patient Blinding & 1 & 1 & 0 & 0 & 1 & 0 & 1 & 1 \\
\hline 19 & Care Provider Blinding & 1 & 1 & 0 & 0 & 0 & 0 & 0 & 0 \\
\hline 20 & Outcome Assessor Blinding & 0 & 0 & 0 & 0 & 1 & 0 & 0 & 0 \\
\hline VIII & Conflicts of Interest & & & & & & & & \\
\hline 21 & Funding and Sponsorship & 2 & 2 & 3 & 2 & 2 & 2 & 2 & 2 \\
\hline 22 & Conflicts of Interest & 3 & 3 & 3 & 3 & 3 & 3 & 3 & 0 \\
\hline Total & 44 & 43 & 28 & 24 & 31 & 18 & 26 & 13 & \\
\hline
\end{tabular}

${ }^{\mathrm{a}}$ Source: Manchikanti L, et al. Assessment of methodological quality of randomized trials of interventional techniques: Development of an interventional pain management specific instrument. Pain Physician 2014; 17:E263-E290 (63). 
Manchikanti L et al.

Table 6. Description of Study Characteristics of Randomized Epidural Trials Assessing the Efficacy of Epidural Injections in Lumbar Central Spinal Stenosis a

\begin{tabular}{|c|c|c|c|c|c|c|c|c|}
\hline Study & $\begin{array}{c}\text { Participants/Inter- } \\
\text { ventions }\end{array}$ & $\begin{array}{l}\text { Outcome Mea- } \\
\text { sures }\end{array}$ & \multicolumn{4}{|c|}{ Pain Relief and Function } & Results & Comment(s) \\
\hline \multicolumn{9}{|l|}{$\begin{array}{l}\text { Study Char- } \\
\text { acteristics }\end{array}$} \\
\hline $\begin{array}{l}\text { Methodolog- } \\
\text { ical Quality } \\
\text { Scoring }\end{array}$ & & & 3 mos. & $6 \mathrm{mos}$ & 12 mos. & 2 years & & \\
\hline \multicolumn{9}{|c|}{ Caudal Epidural } \\
\hline $\begin{array}{l}\text { Manchikanti } \\
\text { et al. } 2012 \\
\text { (9); R, AC, } \\
\text { F; Lumbar } \\
\text { central } \\
\text { spinal ste- } \\
\text { nosis; Qual- } \\
\text { ity Scores: } \\
\text { Cochrane } \\
=11 / 12 ; \text { IPM- } \\
\text { QRB = 44/48 }\end{array}$ & $\begin{array}{c}\text { Total }=100 ; \text { Lidocaine }= \\
50 ; \text { Lidocaine }+ \text { steroid } \\
\text { = 50; } \text { Lidocaine } 0.5 \% \\
\text { vs. lidocaine mixed } \\
\text { with steroid. Average } \\
\text { number of injections = } \\
5 \text { to } 6 \text { for } 2 \text { years }\end{array}$ & $\begin{array}{l}\text { NRS, ODI, em- } \\
\text { ployment status, } \\
\text { opioid intake; } \\
\text { Responsive cate- } \\
\text { gory was defined } \\
\text { as at least } 3 \text { weeks } \\
\text { of significant im- } \\
\text { provement with } \\
\text { the first } 2 \text { proce- } \\
\text { dures. Significant } \\
\text { improvement: } \\
\text { 50\% improve- } \\
\text { ment in pain and } \\
\text { function. }\end{array}$ & $\begin{array}{c}\text { Overall: LA 58\% vs } \\
\text { LA with steroid 48\%; } \\
\text { Responsive: LA 78\% } \\
\text { vs. LA with steroid } \\
65 \%\end{array}$ & $\begin{array}{l}\text { Overall: } \\
\text { LA 54\% } \\
\text { vs LA } \\
\text { with } \\
\text { steroid } \\
\text { 50\%; } \\
\text { Respon- } \\
\text { sive: LA } \\
73 \% \text { vs. } \\
\text { LA with } \\
\text { steroid } \\
68 \%\end{array}$ & $\begin{array}{l}\text { Overall: } \\
\text { LA 44\% } \\
\text { vs LA } \\
\text { with } \\
\text { steroid } \\
\text { 46\%; } \\
\text { Respon- } \\
\text { sive: LA } \\
54 \% \text { vs. } \\
\text { LA with } \\
\text { steroid } \\
62 \%\end{array}$ & $\begin{array}{l}\text { Over- } \\
\text { all: LA } \\
38 \% \\
\text { vs LA } \\
\text { with } \\
\text { steroid } \\
44 \% \\
\text { Re- } \\
\text { spon- } \\
\text { sive: } \\
\text { LA } 51 \% \\
\text { vs. LA } \\
\text { with } \\
\text { steroid } \\
\text { 57\% }\end{array}$ & $\begin{array}{l}\text { - No significant difference between } \\
\text { local anesthetic and local anes- } \\
\text { thetic with steroid with significant } \\
\text { improvement with overall assess- } \\
\text { ment or in the responsive group } \\
\text { participants. } \bullet \text { Nonresponsive } \\
\text { patients: local anesthetic }=13 \text {, ste- } \\
\text { roid }=13 \text {. } \text { Nonresponsive patients } \\
\text { were equal in both groups with a } \\
\text { total of } 26 \%\end{array}$ & $\begin{array}{l}\text { •Double-blind design } \\
\text { in a practical setting; } \\
\text { • Similar results with } \\
\text { local anesthetic or } \\
\text { with local anesthetic } \\
\text { and steroid; • A high } \\
\text { proportion of nonre- } \\
\text { sponsive patients with } \\
\text { 26\%, equal among local } \\
\text { anesthetic only group } \\
\text { and local anesthetic } \\
\text { with steroid group } \\
\text { with } 13 \text { each; • Lack } \\
\text { of placebo controlled } \\
\text { group. }\end{array}$ \\
\hline \multicolumn{9}{|c|}{ Interlaminar Epidural } \\
\hline $\begin{array}{l}\text { Manchikanti } \\
\text { et al. } 2014 \\
\text { (10); R, AC, } \\
\text { F; Central } \\
\text { spinal ste- } \\
\text { nosis Qual- } \\
\text { ity Scores: } \\
\text { Cochrane = } \\
\text { 10/12; IPM- } \\
\text { QRB }=43 / 48\end{array}$ & $\begin{array}{l}\text { Total }=120 \text {; Local } \\
\text { anesthetic }=60 \text {; Local } \\
\text { anesthetic and steroid } \\
=60 ; \text { Local anesthetic } \\
\text { or local anesthetic } \\
\text { with non-particulate } \\
\text { Celestone; Average } \\
\text { number of injections = } \\
5 \text { to } 6 \text { for } 2 \text { years }\end{array}$ & $\begin{array}{l}\text { NRS, ODI, em- } \\
\text { ployment status, } \\
\text { opioid intake; } \\
\text { Responsive } \\
\text { was defined as } \\
\text { those patients } \\
\text { responding with } \\
\text { at least } 3 \text { weeks } \\
\text { of improvement } \\
\text { with the first } \\
2 \text { procedures. } \\
\text { Significant } \\
\text { improvement: } \\
50 \% \text { improve- } \\
\text { ment in pain and } \\
\text { function. }\end{array}$ & $\begin{array}{l}\text { Overall: LA 75\% vs. LA } \\
\text { with steroid 77\%; Re- } \\
\text { sponsive: LA 88\% vs. } \\
\text { LA with steroid } 85 \%\end{array}$ & $\begin{array}{l}\text { Overall: } \\
\text { LA 72\% } \\
\text { vs. LA } \\
\text { with } \\
\text { steroid } \\
77 \% \text {; } \\
\text { Respon- } \\
\text { sive: LA } \\
84 \% \text { vs. } \\
\text { LA with } \\
\text { steroid } \\
87 \%\end{array}$ & $\begin{array}{l}\text { Overall: } \\
\text { LA73\% } \\
\text { vs. LA } \\
\text { with } \\
\text { steroid } \\
\text { 73\%; } \\
\text { Respon- } \\
\text { sive: LA } \\
86 \% \text { vs. } \\
\text { LA with } \\
\text { steroid } \\
\text { 83\% }\end{array}$ & $\begin{array}{l}\text { Over- } \\
\text { all: LA } \\
72 \% \\
\text { vs LA } \\
\text { with } \\
\text { steroid } \\
73 \% \\
\text { Re- } \\
\text { spon- } \\
\text { sive: } \\
\text { LA } 84 \% \\
\text { vs. LA } \\
\text { with } \\
\text { steroid } \\
85 \%\end{array}$ & $\begin{array}{l}\text {-No significant difference between } \\
\text { local anesthetic and local anes- } \\
\text { thetic with steroid with significant } \\
\text { improvement with overall assess- } \\
\text { ment or in the responsive group } \\
\text { participants. } \bullet \text { Nonresponsive } \\
\text { patients: local anesthetic }=9 \text {, } \\
\text { steroid }=7 \text {. }\end{array}$ & $\begin{array}{l}\bullet \text { Positive results in a } \\
\text { large active control } \\
\text { trial. } \bullet \text { Both were } \\
\text { effective in a similar } \\
\text { proportion of patients } \\
\text { with significant im- } \\
\text { provement either with } \\
\text { local anesthetic or local } \\
\text { anesthetic with steroid } \\
\text { were effective. } \bullet \text { Lack } \\
\text { of placebo controlled } \\
\text { group. }\end{array}$ \\
\hline $\begin{array}{l}\text { Lee et al. } \\
2009[68] ; R \text {, } \\
\text { AC, F; Qual- } \\
\text { ity Scores: } \\
\text { Cochrane = } \\
\text { 6/12; IPM-QRB } \\
=28 / 48\end{array}$ & $\begin{array}{l}\text { Total: } 99 \text {; Interlaminar } \\
\text { Group: 42; Bilateral } \\
\text { Transforaminal Group: } \\
\text { 57; Interlaminar Group: } \\
8 \mathrm{~mL} \text { of lidocaine } \\
\text { 0.5\% and } 40 \text { mg of } \\
\text { triamcinolone Transfo- } \\
\text { raminal Group: } 4 \text { mL of } \\
\text { lidocaine } 0.5 \% \text { and } 0.5 \\
\text { mL or } 20 \text { mg of triam- } \\
\text { cinolone acetonide on } \\
\text { each side; Number of } \\
\text { injections: } 1 \text { to } 3\end{array}$ & $\begin{array}{l}\text { NRS, PSI, Roland } 5 \\
\text { point pain score }\end{array}$ & $\begin{array}{c}\text { Transforaminal = } \\
3.39 \text { to } 1.79 \text {; Inter- } \\
\text { laminar =3.31 to 2.19; } \\
\text { SI in both groups }\end{array}$ & NA & NA & NA & $\begin{array}{l}\text { • Both transforaminal and inter- } \\
\text { laminar epidural steroid injections } \\
\text { accomplishes significant pain re- } \\
\text { duction from } 2 \text { weeks to } 4 \text { months } \\
\text { after treatment; • In spinal stenosis, } \\
\text { a more significant reduction in the } \\
\text { Roland } 5 \text { point pain score was seen } \\
\text { with more successful pain improve- } \\
\text { ment using the transforaminal } \\
\text { technique as compared with the } \\
\text { interlaminar technique. }\end{array}$ & $\begin{array}{l}\text { - Short-term follow-up } \\
\text { with positive results, } \\
\text { with inability to draw } \\
\text { conclusions; • Lack } \\
\text { of placebo controlled } \\
\text { group. }\end{array}$ \\
\hline $\begin{array}{l}\text { Koc et al. } \\
2009 \text { (11); R, } \\
\text { AC, F; Qual- } \\
\text { ity Scores: } \\
\text { Cochrane = } \\
\text { 5/12; IPM-QRB } \\
=24 / 48\end{array}$ & $\begin{array}{l}\text { Total: } 29 \text { patients; } \\
\text { Group I: Inpatient } \\
\text { physical therapy = } \\
\text { 10; Group II: Epidural } \\
\text { steroid injections = 10; } \\
\text { Group III: Controls = } \\
\text { 9; Treatment: Epidural } \\
\text { injection: } 10 \text { mL of total } \\
\text { solution with } 60 \text { mg of } \\
\text { triamcinolone, } 3 \text { mL of } \\
\text { 0.5\% bupivacaine, and } \\
5.5 \text { mL of physiologi- } \\
\text { cal saline; Number of } \\
\text { injections: } 1 ;\end{array}$ & $\begin{array}{l}\text { Finger floor dis- } \\
\text { tance, treadmill } \\
\text { walk test, sit to } \\
\text { stand test, weight } \\
\text { carrying test, } \\
\text { Roland-Morris } \\
\text { Disability Index, } \\
\text { and Knotting- } \\
\text { ham Health } \\
\text { Profile }\end{array}$ & $\begin{array}{l}\text { Significant and simi- } \\
\text { lar improvement in } \\
\text { all } 3 \text { groups. }\end{array}$ & $\begin{array}{l}\text { Sig- } \\
\text { nificant } \\
\text { and } \\
\text { similar } \\
\text { im- } \\
\text { prove- } \\
\text { ment } \\
\text { in all } 3 \\
\text { groups. }\end{array}$ & NA & NA & $\begin{array}{l}\text { • All } 3 \text { groups showed significant } \\
\text { improvement from baseline at } 6 \\
\text { month follow up; • Both epidural } \\
\text { steroid and physical therapy groups } \\
\text { have demonstrated significant im- } \\
\text { provement in pain and functional } \\
\text { parameters and no significant } \\
\text { difference was noted between the } \\
2 \text { treatment groups. • Significant } \\
\text { improvements were also noted in } \\
\text { the control group, but pain and } \\
\text { functional assessment scores were } \\
\text { significantly more improved in } \\
\text { the epidural group compared with } \\
\text { controls at the second week. }\end{array}$ & $\begin{array}{l}\bullet \text { A very small study } \\
\text { with positive results, } \\
\text { with inability to draw } \\
\text { conclusions; } \bullet \text { Lack } \\
\text { of placebo controlled } \\
\text { group; } \bullet \text { Inpatient } \\
\text { physical therapy not } \\
\text { practical. }\end{array}$ \\
\hline
\end{tabular}


Manchikanti L et al.

\begin{tabular}{|c|c|c|c|c|c|c|c|c|}
\hline $\begin{array}{l}\text { Wilson-Mac- } \\
\text { Donald et al. } \\
2005(12) ; \mathbf{R} \\
\text { B, AC; Qual- } \\
\text { ity Scores: } \\
\text { Cochrane = } \\
\text { 10/12; IPM- } \\
\text { QRB = 31/48 }\end{array}$ & $\begin{array}{l}\text { Total:32 patients; } \\
\text { Treatment Group: } \\
18 \text { patients; Control } \\
\text { Group: } 14 \text { patients; } \\
\text { Treatment: Epidural in- } \\
\text { jection of } 8 \text { mL of } 0.5 \% \\
\text { bupivacaine with } 40 \\
\text { mg of methylpredniso- } \\
\text { lone; Control Group: } 8 \\
\text { mL of bupivacaine } 0.5 \% \\
\text { and } 80 \text { mg of methyl- } \\
\text { prednisolone placed } \\
\text { outside the epidural } \\
\text { space described as in- } \\
\text { tramuscular. Number } \\
\text { of injections: } 1 \text { to } 2\end{array}$ & $\begin{array}{c}\text { Oxford Pain } \\
\text { Chart and ODI }\end{array}$ & $\begin{array}{l}\text { SI in the treatment } \\
\text { group }\end{array}$ & $\mathrm{U}$ & $\mathrm{U}$ & NA & $\begin{array}{l}\text { There was a significant difference } \\
\text { in pain relief between the } 2 \text { groups } \\
\text { at } 35 \text { days with the epidural group } \\
\text { being better }(\mathrm{P}<0.0004) \text {. This } \\
\text { difference had become significant } \\
10 \text { days after the injection. Patients } \\
\text { with spinal stenosis responded } \\
\text { equally as disc herniation patients. }\end{array}$ & $\begin{array}{l}\text { Small study with in- } \\
\text { ability to draw conclu- } \\
\text { sions despite inclusion } \\
\text { of a placebo group. }\end{array}$ \\
\hline $\begin{array}{l}\text { Fukusaki et } \\
\text { al. 1998 (13); } \\
\text { R, B, AC, PC; } \\
\text { Spinal ste- } \\
\text { nosis; Qual- } \\
\text { ity Scores: } \\
\text { Cochrane = } \\
\text { 5/12; IPM-QRB } \\
=18 / 48\end{array}$ & $\begin{array}{l}\text { Total=53; Epidural sa- } \\
\text { line =16; Mepivacaine } \\
=18 \text {; } \text { Mepivacaine and } \\
\text { methylprednisolone } \\
\text { =19; Saline or mepiva- } \\
\text { caine or a combination } \\
\text { of mepivacaine and } \\
\text { methylprednisolone; } \\
\text { Number of injections } \\
=1 \text { to } 3\end{array}$ & $\begin{array}{l}\text { Walking dis- } \\
\text { tance; Excellent } \\
>100 \mathrm{~m} \text {; Good } \\
20-100 \mathrm{~m}\end{array}$ & $\begin{array}{l}\text { Saline } 6.3 \% ; \mathrm{LA}=5.6 \% \\
\text { LA with steroid 5.3\% }\end{array}$ & NA & NA & NA & $\begin{array}{l}\text { • The steroid group showed } \\
\text { significantly superior results after } \\
\text { one week compared to epidural } \\
\text { saline or epidural mepivacaine. At } \\
3 \text { months, there was no significant } \\
\text { difference and the effect dissipated } \\
\text { in all patients to less than } 10 \% \text { ef- } \\
\text { fectiveness level; • There was no } \\
\text { significant difference between } \\
\text { epidural saline, local anesthetic, } \\
\text { or steroid. }\end{array}$ & $\begin{array}{l}\text { • In this assessment } \\
\text { steroid patients } \\
\text { showed better im- } \\
\text { provement after one } \\
\text { week; however, this } \\
\text { dissipated at the end } \\
\text { of } 3 \text { months. All } 3 \\
\text { groups provided lack } \\
\text { of significant improve- } \\
\text { ment. • There was no } \\
\text { difference between } \\
\text { saline and local anes- } \\
\text { thetic and steroid with } \\
\text { lack of effectiveness } \\
\text { with all } 3 \text { solutions; } \\
\text { - Small study with } \\
\text { short-term follow-up } \\
\text { with inability to reach } \\
\text { conclusions. }\end{array}$ \\
\hline \multicolumn{9}{|c|}{ Transforaminal Epidural } \\
\hline $\begin{array}{l}\text { Lee et al. } \\
2009(14) ; \\
\text { R, AC; Qual- } \\
\text { ity Scores: } \\
\text { Cochrane = } \\
\text { 6/12; IPM-QRB } \\
=28 / 48\end{array}$ & $\begin{array}{l}\text { Total: } 99 \text {; Interlaminar } \\
\text { Group: 42; Bilateral } \\
\text { Transforaminal Group: } \\
\text { 57; Interlaminar Group: } \\
8 \text { mL of lidocaine } \\
\text { 0.5\% and } 40 \text { mg of } \\
\text { triamcinolone; Transfo- } \\
\text { raminal Group: } 4 \text { mL of } \\
\text { lidocaine } 0.5 \% \text { and } 0.5 \\
\text { mL or } 20 \text { mg of triam- } \\
\text { cinolone acetonide on } \\
\text { each side; Number of } \\
\text { injections: } 1 \text { to } 3\end{array}$ & $\begin{array}{l}\text { NRS, PSI, Roland } 5 \\
\text { point pain score }\end{array}$ & $\begin{array}{l}\text { Transforaminal = } \\
3.39 \text { to } 1.79 \text {; Inter- } \\
\text { laminar =3.31 to } 2.19 \text {; } \\
\text { SI in both groups }\end{array}$ & NA & NA & NA & $\begin{array}{l}\text { - Both transforaminal and inter- } \\
\text { laminar epidural steroid injections } \\
\text { accomplishes significant pain re- } \\
\text { duction from } 2 \text { weeks to } 4 \text { months } \\
\text { after treatment; } \bullet \text { In spinal stenosis, } \\
\text { a more significant reduction in the } \\
\text { Roland } 5 \text { point pain score was seen } \\
\text { with more successful pain improve- } \\
\text { ment using the transforaminal } \\
\text { technique as compared with the } \\
\text { interlaminar technique. }\end{array}$ & $\begin{array}{c}\text { • Short-term follow-up } \\
\text { with positive results; • } \\
\text { No placebo group. }\end{array}$ \\
\hline $\begin{array}{l}\text { Nam and } \\
\text { Park, } 2011 \\
\text { (15); R, AC, } \\
\text { F; Lumbar } \\
\text { spinal ste- } \\
\text { nosis; Qual- } \\
\text { ity Scores: } \\
\text { Cochrane = } \\
\text { 8/12; IPM-QRB } \\
=26 / 48\end{array}$ & $\begin{array}{l}\text { Total = } 36 \text {; Lidocaine } \\
=19 \text {; Lidocaine with } \\
\text { steroid = 17; Local anes- } \\
\text { thetic } 0.5 \% \text {; Lidocaine } \\
2 \mathrm{~mL} \text { or } 1.5 \mathrm{~mL} \text { of } 0.5 \% \\
\text { lidocaine and } 20 \mathrm{mg} \text { of } \\
\text { 0.5 mL of triamcino- } \\
\text { lone; Either lidocaine } \\
0.5 \% 2 \mathrm{~mL} \text { or } 1.5 \mathrm{~mL} \text { of } \\
0.5 \% \text {;idocaine with } 20 \\
\text { mg of } 0.5 \mathrm{~mL} \text { of triam- } \\
\text { cinolone; Number of } \\
\text { injections = } 1-3\end{array}$ & VAS, ODI & $\begin{array}{l}\text { Mean VAS lidocaine } \\
\text { group } 4.732 \text { versus } \\
3.829 \text { for steroid } \\
\text { group; Mean ODI } \\
\text { lidocaine group } \\
48.626 \text { and steroid } \\
\text { group } 37.182 ; \text { Base- } \\
\text { line VAS } 7.4 \text { lidocaine } \\
\text { group and } 7.3 \text { steroid } \\
\text { group; Baseline ODI } \\
\text { 62.9 lidocaine group } \\
\text { and 63.0 for steroid } \\
\text { group }\end{array}$ & NA & NA & NA & $\begin{array}{l}\text { • Local anesthetic only or local } \\
\text { anesthetic with steroid were } \\
\text { both effective; • Local anesthetic } \\
\text { with steroid showed significantly } \\
\text { greater improvement. }\end{array}$ & $\begin{array}{l}\text { - Positive results with } \\
\text { local anesthetic and } \\
\text { steroid or local anes- } \\
\text { thetic only at } 3 \text { months; } \\
\text { • Very small study; • } \\
\text { Steroid was superior to } \\
\text { local anesthetic; • No } \\
\text { placebo group. }\end{array}$ \\
\hline
\end{tabular}

\footnotetext{
a Abbreviations: R, Randomized; AC, Active Control; F, Fluoroscopy; B, Blind; PC, Placebo Control; NRS, Numeric Rating Scale; ODI, Oswestry Disability Index; LA, Local Anesthetic; Interventional Pain Management Techniques-Quality Appraisal of Reliability and Risk of Bias Assessment (IPM-QRB); PSI, Patient Satisfaction; SI, Significant Improvement; NA = Not Applicable; VAS, Visual Analog Scale.
} 


\subsection{Meta-Analysis}

No meta-analysis was performed due to limited number of trials in each category and their lack of homogeneity. The evidence for caudal epidural injections in the management of central spinal stenosis is Level II for long-term improvement based on one high-quality, large randomized controlled trial (29) performed under fluoroscopy; there were no trials reporting lack of effectiveness. The evidence for interlaminar epidural injections is Level II based on one high-quality, long-term active controlled trial performed under fluoroscopy with a 2-year follow-up (30) in conjunction with two moderate-quality randomized controlled trials $(68,69)$ that reported short-term efficacy; two moderate-quality trials $(70,71)$ reported lack of efficacy. The evidence for transforaminal epidural injections in the management of spinal stenosis is Level III-IV based on two moderate-quality randomized controlled trials $(68,69)$ for short-term improvement only.

\subsection{Analysis of Evidence}

The results of randomized trials of the effectiveness of epidural injections are shown in Table 6.There is Level II evidence for long-term results using the caudal and interlaminar approaches. The evidence is Level III for shortterm efficacy for the transforaminal approach, based on 2 moderate-quality randomized controlled trials.

\section{Discussion}

The results of this systematic review, based on a highquality methodological quality assessment and qualitative evidence synthesis based on seven randomized trials, showed that caudal epidural injections and lumbar interlaminar epidural injections of local anesthetic with or without steroid provide effective and significant improvement in pain and function in central spinal stenosis. There is Level II evidence for long-term results for caudal and interlaminar approaches. However, the evidence is Level III for short-term efficacy based on two moderatequality randomized controlled trials of transforaminal epidural injections. An interlaminar approach was reported to be superior to a caudal approach and a caudal approach superior to a transforaminal one. The evidence in this systematic review, similar to some systematic reviews previously published (24-26), does not correlate with other systematic reviews (21-23). Three well-performed systematic reviews (24-26) reported efficacy for epidural injections in the management of central spinal stenosis with local anesthetic with or without steroid. These systematic reviews used appropriate methodological quality assessment criteria and evidence synthesis. In contrast, three other systematic reviews $(17,22,23)$ showed lack of efficacy for epidural injections in the management of disability caused by central spinal stenosis of the lumbosacral spine. All three systematic reviews $(17,22,23)$ have been criticized for poor methodological quality assessment and reaching inappropriate conclu- sions. Kovacs et al. (17), comparing surgery versus conservative treatment for symptomatic lumbar spinal stenosis, concluded that in patients with symptomatic lumbar spinal stenosis, implantation of a specific type of device or decompressive surgery, with or without fusion, is more effective than continued conservative treatment when the latter has failed for 3 to 6 months. However, this systematic review, performed in 2011, assessed multiple modalities together without considering only the shortterm effects of single epidural procedures performed with or without fluoroscopy utilization. Furthermore, they failed to include multiple trials. In a systematic review of nonoperative treatments for lumbar spinal stenosis with neurogenic claudication, Ammendolia et al. (22) concluded that moderate- and high-grade evidence for nonoperative treatment was lacking in reference to epidural injections. With a search of the literature through June 2012, they concluded that there was very low quality evidence from a single trial that epidural steroid injections improved pain, function and quality of life up to two weeks compared with home exercise or inpatient physical therapy. Even though they used appropriate criteria, they missed multiple randomized trials published in reference to epidural injections as well as percutaneous adhesiolysis. Bresnahan et al. (23) conducted a systematic review to assess comparative effectiveness studies of epidural steroid injections for lumbar spinal stenosis; they also estimated reimbursement amounts. This assessment was associated with a flawed analysis, a poor search and poor selection criteria (48). The results of the current systematic review are also in contrast to a recently published, highly sensationalized manuscript (20) and editorial (21). The sensationalized manuscript and editorial caught the media's attention and incited confusion for not only the spine community, but also payers and patients. They concluded that epidural injections of glucocorticoids plus lidocaine offered minimal or no short-term benefit compared with epidural injections of lidocaine alone. The editorial emphasized proceeding directly to a surgical intervention. In addition, media statements by the authors emphasized the idea that exercise or surgery might be better options for patients with narrowing of the spinal canal; however, they presented no evidence for this claim (33). As shown in the critical review (33) of the manuscript (20) and the editorial (21), there are severe limitations to this trial and editorial opinion. The design, inclusion criteria, outcomes assessment, data analysis and interpretation, and conclusions of this trial indicate that this highly sophisticated and much publicized randomized trial may not be appropriate and consequently lead to misinformation. The design of trial itself was inappropriate, because it did not include existing randomized trials, and did not include caudal epidural injections or prior conservative management. In addition, it included patients with acute pain and those with multilevel stenosis. Furthermore, this trial (20) included lumbar interlaminar and transforaminal 
epidural injections with highly variable volumes of injectate per patient, with outcomes assessed at 3 and 6 weeks, which is not optimal for a procedure with an average improvement reported to be about three weeks using an instrument which is more appropriately used in acute and subacute low back pain, rather than chronic low back pain. In addition, an analysis of data was hampered by an inadequate subgroup analysis leading to inappropriate interpretation. Based on a review of data, it appears that epidural injections of local anesthetic with steroid were clearly superior at three weeks and possibly at six weeks. Furthermore, both treatments were effective considering baseline to 3-week and 6-week assessments. Thus, an appropriate subgroup analysis would have yielded significant superiority for interlaminar epidural injections compared to transforaminal epidural injections with local anesthetic only or with steroid if the authors had appropriately measured the outcomes with the proportion of patients with greater than $50 \% \mathrm{im}$ provement at 3- and 6-week levels. In addition, there was an inordinate prevalence of complications related to injection therapy, which might be attributed to bilateral transforaminal epidural injections, as well as multilevel transforaminal epidural injections. Correlating symptoms and physical examination findings with imaging results is quite essential as there is no generally accepted "gold standard" for the diagnosis of lumbar spinal stenosis. Thus, patients who are not candidates for surgery may become candidates for interventional techniques, including epidural injections. Patients nonresponsive to epidural injections might be treated with percutaneous adhesiolysis, which has led to favorable results (10, 4956). Surgical interventions described in the management of central spinal stenosis have shown modest results on a long-term basis (5-9, 17, 19, 34-47). The literature reports only modest long-term results with surgery for spinal stenosis; QALY cost is $\$ 77600$ with $62 \%$, or $\$ 48112$ of the total cost, as direct medical costs (47). In contrast, caudal epidural injections have shown to have a cost utility of \$2155 per QALY with direct medical costs (31). In addition, even after the failure of caudal or interlaminar epidural injections, QALY cost of percutaneous adhesiolysis has been determined to be $\$ 2652$ with direct medical costs (55). While surgery is essential in severe symptomatic stenosis, for all other conditions conservative management with epidural injections in conjunction with physical therapy modalities and exercise programs is a cost-effective modality to manage mild to moderate symptomatic central spinal stenosis as well as those patients who have contraindications or unwilling to undergo surgery. However, multiple studies directed at isolating factors that influence outcomes have not provided clinically applicable insights (50, 73-75). The paucity of literature and inability to perform a meta-analysis due to lack of homogeneity may be considered as limitations. Besides, most evidence is derived from active-controlled trials, specifically for long-term improvement. In addition, not consid- ering all randomized controlled trials, irrespective of their size, design, duration of follow-up, or quality and exclusion of observational studies were some other deficiencies. However, there were some major strengths of this systematic review. Previous systematic reviews and guidelines did not report any significant improvement with inclusion of low quality, inappropriate or observational studies. In accordance with our objective of determining efficacy, we showed moderate long-term efficacy for caudal and interlaminar epidural approaches and moderate short-term efficacy for transforaminal epidurals. Thus, our findings showed significant efficacy for caudal and interlaminar epidural injections in lumbar central spinal stenosis. Previous authors of epidural injection systematic reviews $(65,76,77)$ inappropriately used local anesthetic as placebo and performed a meta-analysis, which ultimately yielded inappropriate results $(56,78$ $80)$. While the strength of our review is that it provides qualitative evidence, it is limited since it was unable to provide quantitative information. While a quantitative analysis is crucial, it is not valid if misappropriated. This review also provided up-to-date evidence and demonstrated a significant cost utility analysis. These results are crucial for shared decision-making in which patients are informed about up-to-date evidence and probable outcomes in a balanced manner. Based on the present systematic review and available high-quality randomized controlled trials, the evidence is Level II for long-term, 2-year efficacy for caudal and interlaminar epidural injections with local anesthetic alone or with local anesthetic and steroids, whereas it is Level III for short-term improvement only with transforaminal epidural injections. This systematic review applied strict principles of study design, methodological quality assessment and best-evidence synthesis.

\section{Acknowledgements}

The authors wish to thank Tom Prigge, MA, Laurie Swick, BS, for manuscript review, and Tonie M. Hatton and Diane E. Neihoff, transcriptionists, for their assistance in preparation of this manuscript.

\section{Authors' Contributions}

Study concept and design: Laxmaiah Manchikanti, Alan David Kaye, Joshua Hirsch; data collection: Laxmaiah Manchikanti, Vidyasagar Pampati, Kavita Manchikanti, Alan David Kaye; data analysis and manuscript preparation: Laxmaiah Manchikanti, Kavita Manchikanti, Alan David Kaye, Mark Boswell, Joshua Hirsch; critical revision: Laxmaiah Manchikanti, Alan David Kaye, Mark Boswell, Joshua Hirsch.

\section{Financial Disclosure}

Dr. Kaye is a speaker for Depomed, Inc. Dr. Hirsch is a consultant for Medtronic. 


\section{References}

1. Haig AJ, Tomkins CC. Diagnosis and management of lumbar spinal stenosis. JAMA. 2010;303(1):71-2.

2. Kalichman L, Cole R, Kim DH, Li L, Suri P, Guermazi A, et al. Spinal stenosis prevalence and association with symptoms: the Framingham Study. Spine J. 2009;9(7):545-50.

3. Hall S, Bartleson JD, Onofrio BM, Baker HL, Jr., Okazaki H, O'Duffy JD. Lumbar spinal stenosis. Clinical features, diagnostic procedures, and results of surgical treatment in 68 patients. Ann Intern Med.1985;103(2):271-5.

4. de Schepper EI, Overdevest GM, Suri P, Peul WC, Oei EH, Koes BW, et al. Diagnosis of lumbar spinal stenosis: an updated systematic review of the accuracy of diagnostic tests. Spine (Phila Pa 1976). 2013;38(8):E469-81.

5. Pannell WC, Savin DD, Scott TP, Wang JC, Daubs MD. Trends in the surgical treatment of lumbar spine disease in the United States. Spine J. 2013.

6. Bae HW, Rajaee SS, Kanim LE. Nationwide trends in the surgical management of lumbar spinal stenosis. Spine (Phila Pa 1976). 2013;38(11):916-26.

7. Deyo RA, Mirza SK, Martin BI, Kreuter W, Goodman DC, Jarvik JG. Trends, major medical complications, and charges associated with surgery for lumbar spinal stenosis in older adults. JAMA. 2010;303(13):1259-65.

8. Rajaee SS, Bae HW, Kanim LE, Delamarter RB. Spinal fusion in the United States: analysis of trends from 1998 to 2008. Spine (Phila Pa 1976). 2012;37(1):67-76.

9. Tosteson AN, Tosteson TD, Lurie JD, Abdu W, Herkowitz H, Andersson $\mathrm{G}$, et al. Comparative effectiveness evidence from the spine patient outcomes research trial: surgical versus nonoperative care for spinal stenosis, degenerative spondylolisthesis, and intervertebral disc herniation. Spine (Phila Pa 1976). 2011;36(24):2061-8.

10. Manchikanti L, Abdi S, Atluri S, Benyamin RM, Boswell MV, Buenaventura RM, et al. An update of comprehensive evidencebased guidelines for interventional techniques in chronic spinal pain. Part II: guidance and recommendations. Pain Physician. 2013;16(2 Suppl):S49-283.

11. Manchikanti L, Falco FJ, Singh V, Pampati V, Parr AT, Benyamin $\mathrm{RM}$, et al. Utilization of interventional techniques in managing chronic pain in the Medicare population: analysis of growth patterns from 2000 to 2011. Pain Physician. 2012;15(6):E969-82.

12. Manchikanti L, Pampati V, Falco FJ, Hirsch JA. Assessment of the growth of epidural injections in the medicare population from 2000 to 2011. Pain Physician. 2013;16(4):E349-64.

13. Gupta S, Gupta M, Nath S, Hess GM. Survey of European pain medicine practice. Pain Physician. 2012;15(6):E983-94

14. Manchikanti L, Helm Ii S, Singh V, Hirsch JA. Accountable interventional pain management: a collaboration among practitioners, patients, payers, and government. Pain Physician. 2013;16(6):E635-70.

15. Abbott ZI, Nair KV, Allen RR, Akuthota VR. Utilization characteristics of spinal interventions. Spine J. 2012;12(1):35-43.

16. Bicket MC, Gupta A, Brown C, Cohen SP. Epidural injections for spinal pain: a systematic review and meta-analysis evaluating the "control" injections in randomized controlled trials. Anesthesiology. 2013;119(4):907-31.

17. Kovacs FM, Urrutia G, Alarcon JD. Surgery versus conservative treatment for symptomatic lumbar spinal stenosis: a systematic review of randomized controlled trials. Spine (Phila Pa 1976). 2011;36(20):E1335-51.

18. Radcliff K, Kepler C, Hilibrand A, Rihn J, Zhao W, Lurie J, et al. Epidural steroid injections are associated with less improvement in patients with lumbar spinal stenosis: a subgroup analysis of the Spine Patient Outcomes Research Trial. Spine (Phila Pa 1976). 2013;38(4):279-91.

19. Weinstein JN, Tosteson TD, Lurie JD, Tosteson AN, Blood E, Hanscom B, et al. Surgical versus nonsurgical therapy for lumbar spinal stenosis. NEngl J Med. 2008;358(8):794-810.

20. Friedly JL, Comstock BA, Turner JA, Heagerty PJ, Deyo RA, Sullivan $\mathrm{SD}$, et al. A randomized trial of epidural glucocorticoid injections for spinal stenosis. N Engl J Med. 2014;371(1):11-21.
21. Andersson GB. Epidural glucocorticoid injections in patients with lumbar spinal stenosis. N Engl J Med. 2014;371(1):75-6.

22. Ammendolia C, Stuber K, de Bruin LK, Furlan AD, Kennedy CA, Rampersaud YR, et al. Nonoperative treatment of lumbar spinal stenosis with neurogenic claudication: a systematic review. Spine (Phila Pa 1976). 2012;37(10):E609-16.

23. Bresnahan BW, Rundell SD, Dagadakis MC, Sullivan SD, Jarvik JG, Nguyen H, et al. A systematic review to assess comparative effectiveness studies in epidural steroid injections for lumbar spinal stenosis and to estimate reimbursement amounts. PM R. 2013;5(8):705-14.

24. Parr AT, Manchikanti L, Hameed H, Conn A, Manchikanti KN, Benyamin RM, et al. Caudal epidural injections in the management of chronic low back pain: a systematic appraisal of the literature. Pain Physician. 2012;15(3):E159-98.

25. Manchikanti L, Buenaventura RM, Manchikanti KN, Ruan X, Gupta S, Smith HS, et al. Effectiveness of therapeutic lumbar transforaminal epidural steroid injections in managing lumbar spinal pain. Pain Physician. 2012;15(3):E199-245.

26. Benyamin RM, Manchikanti L, Parr AT, Diwan S, Singh V, Falco FJ, et al. The effectiveness of lumbar interlaminar epidural injections in managing chronic low back and lower extremity pain. Pain Physician. 2012;15(4):E363-404.

27. Ohtori S, Miyagi M, Eguchi Y, Inoue G, Orita S, Ochiai N, et al. Epidural administration of spinal nerves with the tumor necrosis factor-alpha inhibitor, etanercept, compared with dexamethasone for treatment of sciatica in patients with lumbar spinal stenosis: a prospective randomized study. Spine (Phila Pa 1976). 2012;37(6):439-44.

28. Cosgrove JL, Bertolet M, Chase SL, Cosgrove GK. Epidural steroid injections in the treatment of lumbar spinal stenosis efficacy and predictability of successful response. Am J Phys Med Rehabil. 2011;90(12):1050-5.

29. Manchikanti L, Cash KA, McManus CD, Pampati V, Fellows B. Results of 2-year follow-up of a randomized, double-blind, controlled trial of fluoroscopic caudal epidural injections in central spinal stenosis. Pain Physician. 2012;15(5):371-84.

30. Manchikanti L, Cash KA, McManus CD, Damron KS, Pampati V, Falco FJE. A randomized, double-blind controlled trial of lumbar interlaminar epidural injections in central spinal stenosis: 2-year follow-up. Int J Phys Med Rehab. 2014;2(1):179.

31. Manchikanti L, Falco FJ, Pampati V, Cash KA, Benyamin RM, Hirsch JA. Cost utility analysis of caudal epidural injections in the treatment of lumbar disc herniation, axial or discogenic low back pain, central spinal stenosis, and post lumbar surgery syndrome. Pain Physician. 2013;16(3):E129-43.

32. Ploumis A, Christodoulou P, Wood KB, Varvarousis D, Sarni JL, Beris A. Caudal vs transforaminal epidural steroid injections as short-term (6 months) pain relief in lumbar spinal stenosis patients with sciatica. Pain Med. 2014;15(3):379-85.

33. Manchikanti L, Candido KD, Kaye AD, Boswell MV, Benyamin RM, Falco FJ, et al. Randomized trial of epidural injections for spinal stenosis published in the New England Journal of Medicine: further confusion without clarification. Pain Physician. 2014;17(4):E475-88.

34. Kim CH, Chung CK, Park CS, Choi B, Hahn S, Kim MJ, et al. Reoperation rate after surgery for lumbar spinal stenosis without spondylolisthesis: a nationwide cohort study. Spine J. 2013;13(10):1230-7.

35. Skolasky RL, Maggard AM, Thorpe RJ, Wegener ST, Riley LH, 3rd. United States hospital admissions for lumbar spinal stenosis: racial and ethnic differences, 2000 through 2009. Spine (Phila Pa 1976). 2013;38(26):2272-8.

36. Desai A, Bekelis K, Ball PA, Lurie J, Mirza SK, Tosteson TD, et al Variation in outcomes across centers after surgery for lumbar stenosis and degenerative spondylolisthesis in the spine patient outcomes research trial. Spine (Phila Pa 1976). 2013;38(8):678-91.

37. Atlas SJ, Keller RB, Wu YA, Deyo RA, Singer DE. Long-term outcomes of surgical and nonsurgical management of lumbar spinal stenosis: 8 to 10 year results from the maine lumbar spine study. Spine (Phila Pa 1976). 20 05;30(8):936-43. 
38. Lad SP, Babu R, Baker AA, Ugiliweneza B, Kong M, Bagley CA, et al. Complications, reoperation rates, and health-care cost following surgical treatment of lumbar spondylolisthesis. J Bone Joint Surg Am. 2013;95(21).

39. Epstein NE. Are recommended spine operations either unnecessary or too complex? Evidence from second opinions. Surg Neurol Int. 2013;4(Suppl 5):S353-8.

40. Modhia U, Takemoto S, Braid-Forbes MJ, Weber M, Berven SH. Readmission rates after decompression surgery in patients with lumbar spinal stenosis among Medicare beneficiaries. Spine (Phila Pa 1976). 2013;38(7):591-6.

41. Fu R, Selph S, McDonagh M, Peterson K, Tiwari A, Chou R, et al. Effectiveness and harms of recombinant human bone morphogenetic protein-2 in spine fusion: a systematic review and metaanalysis. Ann Intern Med. 2013;158(12):890-902.

42. Chopko BW. Long-term results of percutaneous lumbar de compression for LSS: two-year outcomes. Clin J Pain. 2013; 29(11):939-43.

43. Deyo RA, Martin BI, Ching A, Tosteson AN, Jarvik JG, Kreuter $\mathrm{W}$, et al. Interspinous spacers compared with decompression or fusion for lumbar stenosis: complications and repeat operations in the Medicare population. Spine (Phila Pa 1976). 2013;38(10):865-72

44. Chen H, Kelling J. Mild procedure for lumbar decompression: a review. Pain Pract. 2013;13(2):146-53.

45. Stromqvist BH, Berg S, Gerdhem P, Johnsson R, Moller A, Sahlstrand $\mathrm{T}$, et al. X-stop versus decompressive surgery for lumbar neurogenic intermittent claudication: randomized controlled trial with 2-year follow-up. Spine (Phila Pa 1976). 2013; 38(17):1436-42.

46. Rampersaud YR, Tso P, Walker KR, Lewis SJ, Davey JR, Mahomed $\mathrm{NN}$, et al. Comparative outcomes and cost-utility following surgical treatment of focal lumbar spinal stenosis compared with osteoarthritis of the hip or knee: part 2--estimated lifetime incremental cost-utility ratios. Spine J. 2014;14(2):244-54.

47. Tosteson AN, Lurie JD, Tosteson TD, Skinner JS, Herkowitz H, Albert T, et al. Surgical treatment of spinal stenosis with and with out degenerative spondylolisthesis: cost-effectiveness after 2 years. Ann Intern Med. 2008;149(12):845-53.

48. Manchikanti L, Datta S, Hirsch JA. Re: a systematic review to assess comparative effectiveness studies in epidural steroid injections for lumbar spinal stenosis and to estimate reimbursement amounts. PM R. 2014;6(5):463-4.

49. Manchikanti L, Datta S, Gupta S, Munglani R, Bryce DA, Ward SP, et al. A critical review of the American Pain Society clinical practice guidelines for interventional techniques: part 2. Therapeutic interventions. Pain Physician. 2010;13(4):E215-64.

50. Choi E, Nahm FS, Lee PB. Evaluation of prognostic predictors of percutaneous adhesiolysis using a Racz catheter for post lumbar surgery syndrome or spinal stenosis. Pain Physician. 2013;16(5):E531-6.

51. Park CH, Lee SH, Lee SC. Preliminary results of the clinical effectiveness of percutaneous adhesiolysis using a Racz catheter in the management of chronic pain due to cervical central stenosis. Pain Physician. 2013;16(4):353-8.

52. Manchikanti L, Cash KA, McManus CD, Pampati V. Assessment of effectiveness of percutaneous adhesiolysis in managing chronic low back pain secondary to lumbar central spinal canal stenosis. Int J Med Sci. 2013;10(1):50-9.

53. Koh WU, Choi SS, Park SY, Joo EY, Kim SH, Lee JD, et al. Transforaminal hypertonic saline for the treatment of lumbar lateral canal stenosis: a double-blinded, randomized, active-control trial. Pain Physician. 2013;16(3):197-211.

54. Park $\mathrm{CH}$, Lee SH. Effectiveness of percutaneous transforamina adhesiolysis in patients with lumbar neuroforaminal spinal stenosis. Pain Physician. 2013;16(1):E37-43.

55. Manchikanti L, Helm S, 2nd, Pampati V, Racz GB. Cost Utility Analysis of Percutaneous Adhesiolysis in Managing Pain of Postlumbar Surgery Syndrome and Lumbar Central Spinal Stenosis. Pain Pract. 2014.

56. Helm Ii S, Benyamin RM, Chopra P, Deer TR, Justiz R. Percutaneous adhesiolysis in the management of chronic low back pain in post lumbar surgery syndrome and spinal stenosis: a systematic review. Pain Physician. 2012;15(4):E435-62.

57. Furlan AD, Pennick V, Bombardier C, van Tulder M, Editorial Board CBRG. 2009 updated method guidelines for systematic reviews in the Cochrane Back Review Group. Spine (Phila Pa 1976). 2009;34(18):1929-41

58. Liberati A, Altman DG, Tetzlaff J, Mulrow C, Gotzsche PC, Ioannidis JP, et al. The PRISMA statement for reporting systematic reviews and meta-analyses of studies that evaluate health care interventions: explanation and elaboration. Ann Intern Med. 2009;151(4):W65-94.

59. Manchikanti L, Falco FJ, Singh V, Benyamin RM, Racz GB, Helm S, 2nd, et al. An update of comprehensive evidence-based guidelines for interventional techniques in chronic spinal pain. Part I: introduction and general considerations. Pain Physician. 2013;16(2 Suppl):S1-48

60. Hrobjartsson A, Gotzsche PC. Placebo interventions for all clinical conditions. Cochrane Database Syst Rev. 2010(1):CD003974.

61. Kaptchuk TJ, Friedlander E, Kelley JM, Sanchez MN, Kokkotou E Singer JP, et al. Placebos without deception: a randomized controlled trial in irritable bowel syndrome. PLoS One. 2010;5(12).

62. Manchikanti L, Giordano J, Fellows B, Hirsch JA. Placebo and nocebo in interventional pain management: a friend or a foe--or simply foes? Pain Physician. 2011;14(2):E157-75.

63. Manchikanti L, Hirsch JA, Cohen SP, Heavner JE, Falco FJ, Diwan $\mathrm{S}$, et al. Assessment of methodologic quality of randomized trials of interventional techniques: development of an interventional pain management specific instrument. Pain Physician. 2014;17(3):E263-90.

64. Manchikanti L, Falco FJ, Benyamin RM, Kaye AD, Boswell MV Hirsch JA. A modified approach to grading of evidence. Pain Phy sician. 2014;17(3):E319-25.

65. Staal JB, de Bie RA, de Vet HC, Hildebrandt J, Nelemans P. Injection therapy for subacute and chronic low back pain: an updated $\mathrm{Co}-$ chrane review. Spine (Phila Pa 1976). 2009;34(1):49-59.

66. Harris RP, Helfand M, Woolf SH, Lohr KN, Mulrow CD, Teutsch SM, et al. Current methods of the US Preventive Services Task Force: review of the process. Am J Prev Med. 2001;20(3 Suppl):21-35.

67. Nam HS, Park YB. Effects of transforaminal injection for degenerative lumbar scoliosis combined with spinal stenosis. Ann Rehabil Med. 2011;35(4):514-23.

68. Lee JH, An JH, Lee SH. Comparison of the effectiveness of interlaminar and bilateral transforaminal epidural steroid injections in treatment of patients with lumbosacral disc herniation and spinal stenosis. Clin J Pain. 2009;25(3):206-10.

69. Koc Z, Ozcakir S, Sivrioglu K, Gurbet A, Kucukoglu S. Effectiveness of physical therapy and epidural steroid injections in lumbar spinal stenosis. Spine (Phila Pa 1976). 2009;34(10):985-9.

70. Fukusaki M, Kobayashi I, Hara T, Sumikawa K. Symptoms of spinal stenosis do not improve after epidural steroid injection. Clin JPain.1998;14(2):148-51.

71. Wilson-MacDonald J, Burt G, Griffin D, Glynn C. Epidural steroid injection for nerve root compression: A RANDOMISED, CONTROLLED TRIAL. J Bone Joint Surg Br. 2005;87-B(3):352-5.

72. Milburn J, Freeman J, Steven A, Altmeyer W, Kay D. Interlaminar epidural steroid injection for degenerative lumbar spinal cana stenosis: does the intervertebral level of performance matter? Ochsner J. 2014;14(1):62-6.

73. Kim HJ, Yeom JS, Lee JW, Chang BS, Lee CK, Lee GW, et al. The influence of pain sensitivity on the treatment outcome of transforaminal epidural steroid injection in patients with lumbar spinal stenosis. Pain Pract. 2014;14(5):405-12.

74. Kim HJ, Suh BG, Lee DB, Lee GW, Kim DW, Kang KT, et al. The influence of pain sensitivity on the symptom severity in patients with lumbar spinal stenosis. Pain Physician. 2013;16(2):135-44.

75. Tomkins-Lane CC, Conway J, Hepler C, Haig AJ. Changes in objectively measured physical activity (performance) after epidura steroid injection for lumbar spinal stenosis. Arch Phys Med Rehabil. 2012;93(11):2008-14

76. Chou R, Huffman L. Guideline for the Evaluation and Management of Low Back Pain: Evidence Review.Glenview: American Pain Society; 2009. 


\section{Manchikanti L et al.}

77. Pinto RZ, Maher CG, Ferreira ML, Hancock M, Oliveira VC, McLachlan AJ, et al. Epidural corticosteroid injections in the management of sciatica: a systematic review and meta-analysis. Ann Intern Med. 2012;157(12):865-77.

78. Manchikanti L, Falco FJE, Hirsch JA. Epidural corticosteroid injections in the management of sciatica. Ann Intern Med. 2012;157:865-77.
79. Chou R, Atlas SJ, Loeser JD, Rosenquist RW, Stanos SP. Guideline warfare over interventional therapies for low back pain: can we raise the level of discourse? J Pain. 2011;12(8):833-9.

80. Manchikanti L, Benyamin RM, Falco FJ, Caraway DL, Datta S, Hirsch JA. Guidelines warfare over interventional techniques: is there a lack of discourse or straw man? Pain Physician. 2012;15(1):E1-E26. 